\title{
FEMINIZING TUMOURS OF THE TESTIS
}

\author{
P. Paton Philip, M.ChIR., F.R.C.S.* \\ Senior Surgical Registrar, St. Bartholomerw's Hospital, London, E.C. I
}

Certain tumours of the testis in man cause symptoms of a feminizing nature and arouse interest and comment out of all proportion to the frequency of their occurrence. Although these tumours are rare, the literature is extensive, as most of the cases tend to be reported, and their hormonal effects have been the subject of much conjecture and speculation.

Despite all that has been written, this particular aspect of hormone abnormality still remains obscure and complicated.

Some authors have introduced new nomenclature and have attempted to classify the tumours from the standpoint of morbid histological studies; but mere histology alone is no basis for classification of these rare and interesting neoplasms. Until they are more fully investigated any attempt at classification is premature, and no real progress can be made in their elucidation.

Such investigations must not only be from an histological point of view, but must also include pre-operative and post-operative hormonal assays and biosynthetic studies incorporating tumour tissue.

Mostofi et al., ${ }^{24}$ in a recent and authoritative article, describe a group of tumours characterized by a wide variety of histological appearances arising from the primitive gonadal mesenchyme. They call these neoplasms " specialized gonadal stromal tumours'. In a small proportion of their cases gynaecomastia, as evidence of feminization, was reported. This article does much to simplify matters and dispenses with some misleading nomenclature which has been used in the past. These authors have vast experience and almost unlimited material to call upon from the American Armed Forces Institute of Pathology. A further article by them on the subject of interstitial cell tumours of the testis is eagerly awaited and will undoubtedly make a further contribution towards the elucidation and further study of these fascinating tumours.

\footnotetext{
*At present on exchange scheme at Veterans' Hospital, Denver, Colorado, U.S.A.
}

Teilum $^{32,33,34}$ has made an extensive study of $\overrightarrow{\vec{\omega}}$ testicular and ovarian tumours and from the mor- $\mathscr{\sim}$ phological viewpoint has attempted to compare and 8 relate these tumours one with another. $\mathrm{He}$ has 3 . suggested that the 'androblastoma' of the testis is identical with that of the ovary, and also that the testicular tumour which resembles the granulosa- $\vec{\omega}$ celled tumour of the ovary is identical with that $\vec{\theta}$ tumour. There is no doubt that a time will come when more is known about the origin and nature of tumours of the ovary and testis, and it may well be that our knowledge will then justify these conceptions. However, until we obtain further and more detailed biochemical studies, such comparisons between tumours of the male and femalo gonads and attempts at their classification base solely on morphological studies tend only to adđే more confusion to present nomenclature.

The tumours of the testicle to be described are grouped together for no other reason than that they are capable of producing symptoms of $\mathbb{\otimes}$ feminization.

\section{Interstitial Cell or Leydig Cell Tumours}

These are by far the most interesting and remarkable tumours in the group. They form about I per cent. of all testicular tumours in humans, ${ }^{9}$ and have also been reported in various species of animals. Their great interest lies in the fact that 3 two distinct varieties exist in humans, the prepubertal and post-pubertal cases. In the prepubertal cases reported (average age five years) the symptoms are almost always those of sexual precocity, with prominent external genitalia, deep ' male' voice and sometimes enlargement of the opposite testis. In very few cases have adequate $O$ hormonal assays been performed, but nevertheless $N$ the symptoms are clearly those of excessive andro- N gen production. Cook et al., ${ }^{6}$ in a five-year-old ${ }_{\sigma}$ child with a Leydig cell tumour, identified the hormone as 3-hydroxy-17-ketosteroid, which fits the pattern of androsterone. In the majority of $\stackrel{\oplus}{+}$ cases reported complete retrogression of symptoms followed orchidectomy.

In adults the hormonal symptoms produced are 
entirely different, despite the fact that histologically the tumours appear to be identical.

Most post-pubertal cases occur at about 30 years of age, and in less than half of the cases reported there are no symptoms of endocrine disturbance. The patient may present with enlargement of the testicle or the tumour may be found at routine examination. It may be an incidental finding at operation for undescended testicles or hernial repairs, or occasionally may be discovered at autopsy.

In the remainder of the cases, more than half, symptoms of a feminizing nature are present, such as gynaecomastia, impotence and decreased libido.

Such hormonal assays that have been performed on adults with interstitial cell tumours and symptoms of feminization seem to vary considerably. In a case reported by Hermann et al. ${ }^{15}$ with pronounced gynaecomastia, decreased libido and a typical histological picture, the oestrogen excretion was found to be only slightly above normal before operation, whereas the excretion of androsterone and aetiocholanolone (excretion metabolites of testosterone) were appreciably decreased. A similar case of Decourt et al. ${ }^{7}$ exhibited marked feminizing symptoms with only a very moderate degree of biochemical change found on hormonal assay. They suggest that the findings indicate an increased susceptibility of peripheral receptors, abnormal hormonal elimination (which is qualitative rather than quantitative) and an imbalance of secretion of hypophyseal stimulators as a result of the autonomous secretion of the interstitial cell tumour.

In the case of a young adult of 22 years, reported by the author elsewhere, ${ }^{27}$ typical symptoms of feminization were apparent. Gynaecomastia had first appeared two years before admission to hospital, and one year before admission he was treated by his private doctor with testosterone injections, which caused the swelling of the breasts to subside temporarily. When seen at hospital he had well-marked gynaecomastia affecting both breasts, hyper-pigmentation of the areolae and loss of hair from the chest and pubic region, and he complained of loss of libido. The left testicle was found to be smaller than average, a small tumour was palpable in the body of the right testicle and a small vaginal hydrocele was found to be present. The Aschheim-Zondek test was negative and the excretion of 17 -ketosteroids was within normal limits, being $12.7 \mathrm{mg}$. in 24 hours. Orchidectomy was performed and on slicing open the testis a spherical, encapsulated tumour was seen, measuring 2 to $3 \mathrm{~cm}$. in diameter (see Fig. I). Section confirmed a typical interstitial cell tumour with no evidence of malignancy (see Fig. 2).

At follow-up two months later the left testicle

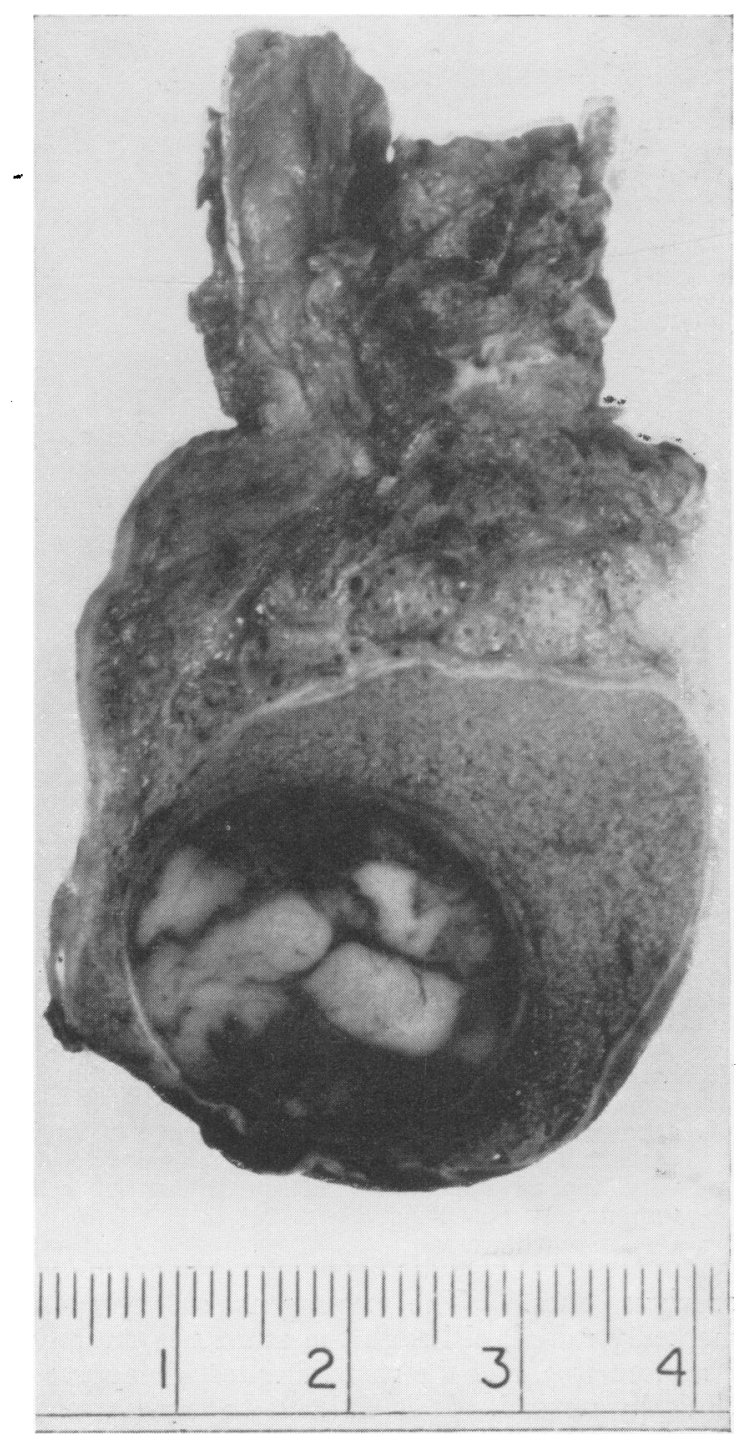

FIG. I.-Interstitial cell tumour. Right testis, removed at operation and bisected to show the typical spherical, encapsulated appearance of the tumour in the body of the testis. From a male aged 22, with feminizing symptoms and high oestrogen output.

had increased in size, the patient had grown more hair on his chest and the gynaecomastia had disappeared. His libido had returned to normal. A hormone survey showed the following results: Oestrone 7.6, oestradiol 2.9, oestriol $14.9 \mu \mathrm{g}$.; total $25.4 \mu \mathrm{g}$. in 24 hours. This value is high, as the upper limit of normal is considered to be about I $7.8 \mu \mathrm{g}$. for an entire man. ${ }^{5}$ A further hormone survey was performed about one year after orchidectomy and the results were identical with the 


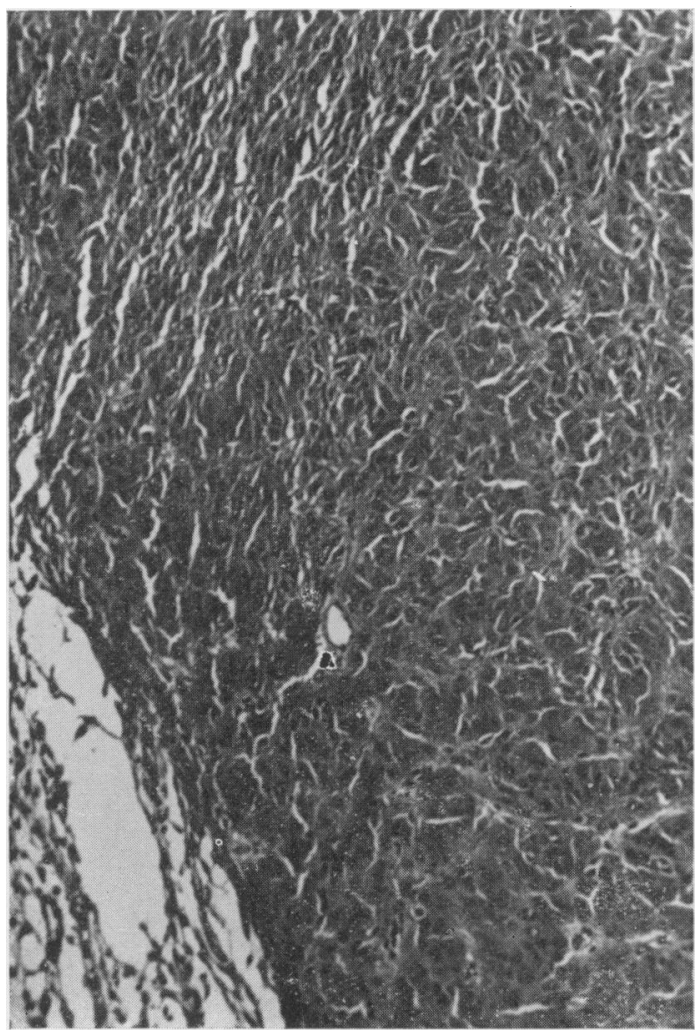

FIG. 2.-Interstitial cell tumour. A section of the tumour shown in Fig. I. The interstitial cells are arranged in a pattern strongly suggestive of liver cords. There is no evidence of malignancy. A very typical appearance of an interstitial cell tumour. $\times 75$.

previous ones. The oestrogens still remain markedly raised, although the patient is entirely symptom-free, and the remaining testicle appears clinically normal. It is difficult to explain why the oestrogen excretion still remains high and no similar case has been found in the literature. In other reported cases the response to orchidectomy has been a reduction in oestrogen excretion to below normal levels.

Typical interstitial cell tumours can be induced in animals by the administration of oestrogens, and many experiments have been performed, using different oestrogens: Bonser and Robson ${ }^{3}$ used oestradiol diproprionate. Hooker et al. ${ }^{16}$ produced typical interstitial cell tumours with metastases in mice with oestradiol benzoate injections. Shimkin et al. ${ }^{30}$ produced the same effect in mice with implants of stilboestrol pellets.

It has been suggested, on the basis of these experimental tumours, that interstitial cell tumours in man are caused by excessive stimulation of

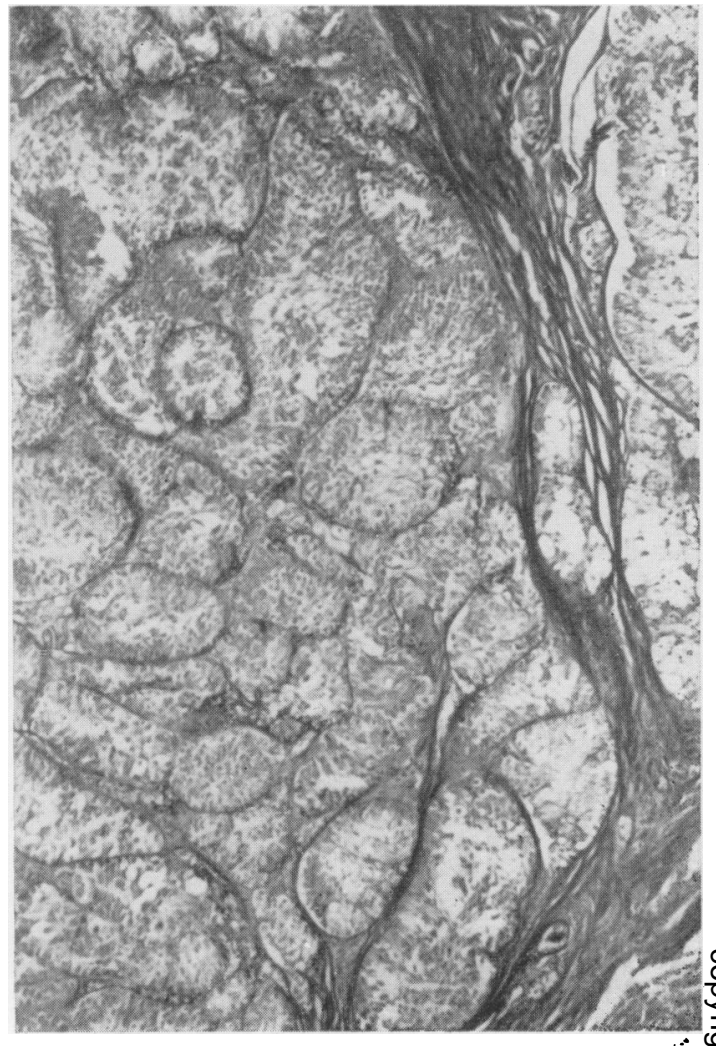

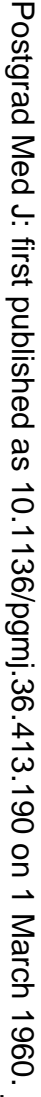

FIg. 3.-Sertoli cell tumour. From a dog aged 14 years with 5 years' history of testicular swelling. This is a typical appearance of such a tumour, and shows the compact alveolar masses of cells, divided by thick fibrous trabeculae. H. and E. $\times 40$.

oestrogen by the anterior pituitary, which causes the formation of the testicular tumour, the gynaecomastia, impotence and loss of libido. McCullagh and Rossmiller ${ }^{22}$ reported gynaecomastia in males who received large doses of testosterone. Testosterone seems to have had quite the opposite effect in the case just described! Twombly et al. ${ }^{35}$ found that anterior pituitary extract caused interstitial cell hyperplasia and gynaecomastia in animals. However, despite much speculation, no really satisfactory explanation has been suggested to account for the fact that typical interstitial cell tumours in adults can give rise to the production of oestrogens and feminizing symptoms. One would expect these tumours to produce androgens, as they do in the pre-pubertal cases. One adult case reported by Venning et $a .^{36}$ was, in fact, found to be excreting as much as $1,015 \mathrm{mg}$. of I 7-ketosteroids daily, but this is an exception to the general rule, and other authors (Cook et al., ${ }^{6}$ Newns $^{25}$ and Philip ${ }^{27}$ ) have reported ex- 


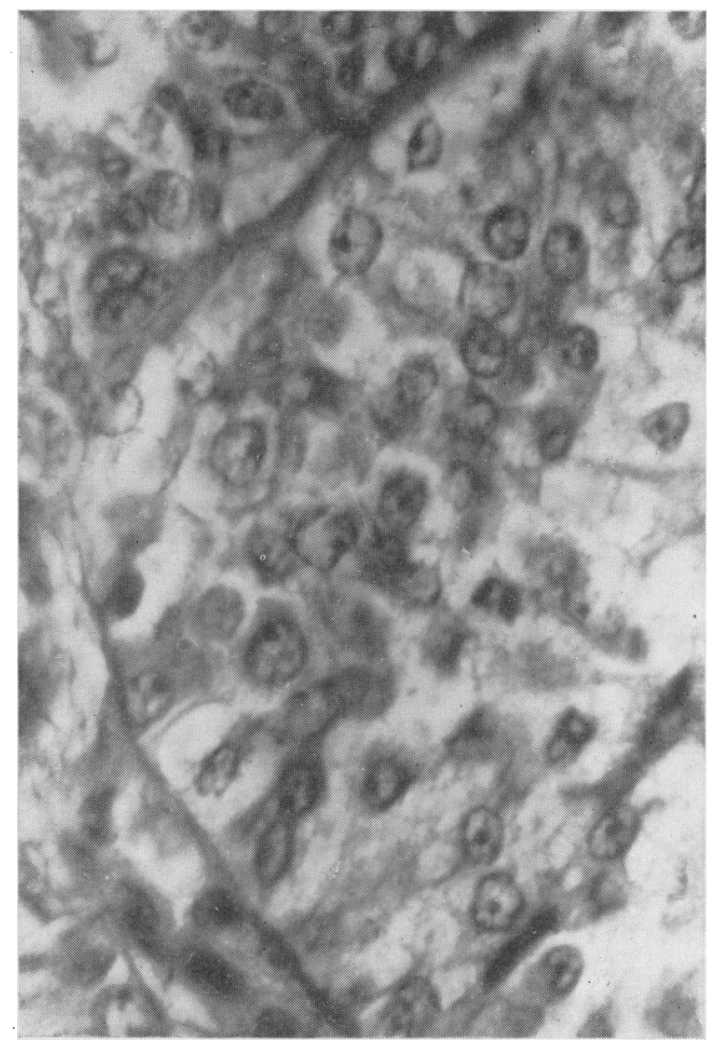

Fig. 4.- Sertoli cell tumour. A higher powered view of the section in Fig. 3, to show individual Sertoli cells. H. and E. $\times$ ioo.

cretion to be within normal limits in post-pubertal cases. There is no doubt that these tumours are capable of producing both male and female hormones and further research would be most profitable.

It could be that in adults with interstitial cell tumours and apparently no symptoms the tumour may be producing androgens and any symptoms might pass unnoticed. Similarly, symptoms may pass unnoticed in children before puberty if excessive oestrogens are being elaborated by the tumour.

\section{Sertoli Cell Tumours}

The microphotographs shown in Figs. 3 and 4 are typical sections of a Sertoli cell tumour from a poodle dog aged 14 years. An enlargement of one testicle had been present for five years before orchidectomy, but unfortunately no further details of symptoms are available. Tumours of the sustentacular cells of Sertoli are quite common in dogs, but extremely rare in humans; in fact, some authors doubt whether genuine Sertoli cell tumours have ever been reported in humans. However, Teilum ${ }^{32}$ reports a Sertoli cell tumour in a 53-year-old male, giving rise to gynaecomastia. Stalker and Hendry ${ }^{31}$ discuss hyperplasia and neoplasia of the Sertoli cell and describe one case in a 17 -year-old male with no endocrine symptoms, but with undoubted Sertoli cell tumour formation. Innes ${ }^{19}$ classified these tumours in dogs as ' tubular adenomata ' and reports $I_{5}$ such cases from a study of 52 animal testicular tumours. In five of these the testis was found to be ectopic and two cases gave rise to feminizing symptoms.

The first histological description of Sertoli cell tumours in the dog was given by Peyron ${ }^{26}$ some 38 years ago. Huggins and Moulder ${ }^{18}$ describe five dogs with feminizing testicular tumours of spontaneous origin, all sexually attractive to other dogs, and all with hypertrophy of mammary papillae. One dog lactated spontaneously, two lactated after prolactin injections. Seven testicular tumours were present in the five dogs (bilateral tumours in two dogs). The tumours were classified as Sertoli cell tumours by these authors, the evidence being based on histochemical study of the lipoids and an oestrogen extraction and assay. The oestrogen content of the cells was found to be considerable. In one case the oestrogen content of the lipoidrich neoplasm was equivalent to $0.07 \mathrm{mg}$. $/ \mathrm{km}$. on bioassay, calculated as $\alpha$-oestradiol benzoate, being twice the content of the ovaries at oestrus and one-third of the amount in equine testisthe richest known source of oestrogen. The 'feminizing' symptoms of such tumours are assumed to be caused by the excessive oestrogen production of the Sertoli cells.

Many authors suggest that interstitial cell tumours producing symptoms of feminization in adults are, in reality, Sertoli cell tumours elaborating oestrogens. However, histologically the two tumours are quite different and there is no reason why they should be mistaken for one another. Certain cases of male pseudohermaphroditism are found to have 'multiple tubular adenomata' in their ectopic testes, absent ovaries and wellmarked gynaecomastia. Such cases were first investigated by Pick in $1905,{ }^{28}$ and later by Krückmann in $1937 .^{21}$ The symptoms of gynaecomastia in such cases can be relieved by bilateral orchidectomy. The Sertoli cell is generally accepted as giving rise to these tumours. Witschi and Mengert ${ }^{40}$ found an abundance of Sertoli cells in abdominal testes of human hermaphrodites, to which they ascribed the production of oestrogen. Oestrogen was being excreted in the urine and disappeared after castration. Also ' tubular adenomata' were reported in cryptorchid testes by Vines. ${ }^{38}$ 'Sertoli cell adenomata' are thus seen on occasion in abnormal, immature and undescended 


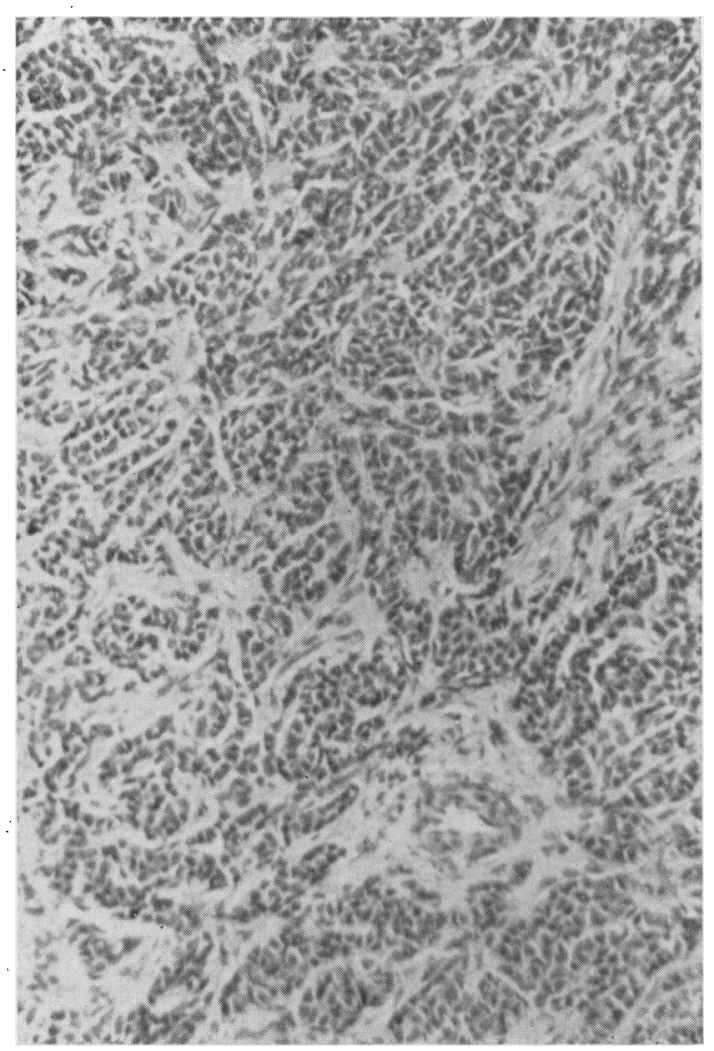

FIG. 5.-Specialized gonadal stromal tumour of testis. The tumour structure is of ' mixed ' type containing spindle and interstitial cells. The patient, a young adult, had no endocrine symptoms.

testes, although in such cases every gradation can be found between mere hyperplasia of the cells, through nodules of tubular hyperplasia, to actual Sertoli cell tumour formation.

\section{Specialized Gonadal Stromal Tumours}

This description was coined by Mostofi et al. ${ }^{24}$ to describe tumours of the testis whose histological picture varied from fairly differentiated epithelial forms resembling Sertoli cells or granulosa cells to a variety consisting almost entirely of fibroblast-like cells. This nomenclature dispensed with such names as 'granulosa-celled tumours' and ' androblastomata'. The name Sertoli cell tumour, however, should not lose its identity and be included in this group, because it is so obviously well defined and has such a typical histological picture. The cell pattern of these tumours (23 reported) varied considerably. Five of the reported cases consisted entirely of epithelial cells resembling Sertoli cells, granulosa cells, interstitial cells and lutein cells and the rest contained, in additions spindle-shaped cells. Gynaecomastia was present,

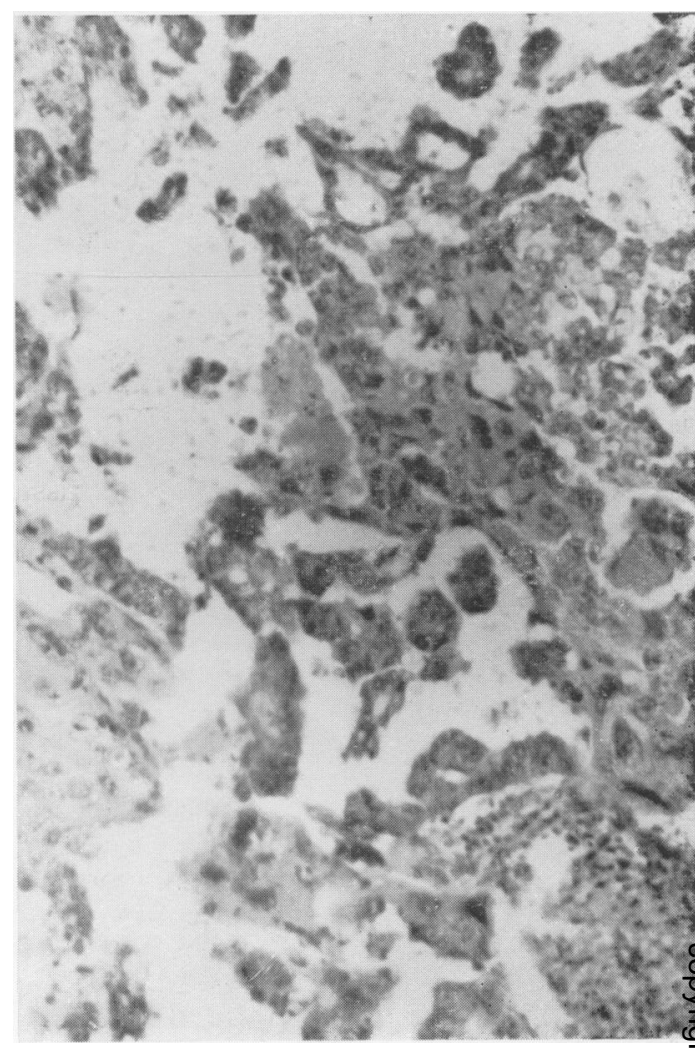

Fig. 6.-Section of chorionepitheliomatous metastasis in lymph gland $\times 100$.

in two of the reported cases and seven from the literature. The authors suggest that these tumours arise from cells of the specialized gonadal stroma rather than from the germ cells of the testis. Fig. 5 吾 is a section of one of these specialized gonadal stromal tumours ('androblastoma') and the 3 tumour structure is of mixed type, containing spindle and interstitial cells. This particular specimen was from an adult male and no particular $\delta$ hormonal symptoms were apparent.

\section{Chorionepithelioma of the Testis}

This is a rare, highly malignant and invasive $\frac{D}{0}$ tumour and metastases may arise from a relatively small primary growth. Gynaecomastia is often $\sigma$ associated with choriogenic tumours of the testis. $N$ The patient may present with a testicular swelling, N enlargement of the breasts, hyperplasia of the areolae and symptoms of impotence or loss of libido. The testicular growth may contain obvious $\frac{0}{\Phi}$ chorionic elements on section and after orchid- $\stackrel{\infty}{?}$ ectomy the following sequence of events may 0 occur: (i) If metastases are already present the 'feminizing symptoms' and the gynaecomastia 
will remain. (ii) If no metastases are present the gynaecomastia will disappear, only to return again if, and when, metastases occur.

A teratoma of the testis, containing apparently only mature elements, on section, may give rise to symptoms of choriogenic gynaecomastia. In some such cases, of course, a small area of chorionic tissue could be missed, despite careful and serial sectioning of the whole tumour, but a number of cases are on record where apparently very welldifferentiated and mature teratomata have given rise to chorionepitheliomatous metastases. Two such cases are described by Brewer, ${ }^{4}$ in which section of the tumours showed no chorionic tissue, but both patients died of chorionepitheliomatous metastases.

The section of a cervical lymph gland in Fig. 6 is from a young adult male who presented with a testicular swelling and no other symptoms. The tumour was removed and found to be a teratoma containing mature elements only; despite diligent sectioning of the whole tumour, no chorionic elements were found. Six months later the patient developed gynaecomastia and impotence; an enlarged cervical gland was removed for biopsy and found to contain a chorionepitheliomatous metastasis. A series of 135 cases of choriogenic tumours of the testis, with gynaecomastia, was reviewed by Gilbert.10 $\mathrm{He}$ made a detailed study of 46 cases resulting from a primary or metastatic chorionepitheliomatous tumour of the testicle and found the following characteristics: the gynaecomastia was usually bilateral, with glandular tissue hyperplasia, and was often the only clinical symptom present. There was enlargement or hyperpigmentation of the areolae and physiological activity of the breasts, characterized by either gross or microscopic secretion.

High titres of choriogonadotrophic hormones and the excretion of abnormally large amounts of oestrogens were found. Histological changes in the pituitary gland of adenomatosis, acidophilia and basophilia, frequently described as "pregnancy changes', were often present. $\mathrm{He}$ also found, in some cases, hyperplasia of the prostate and seminal vesicles. In half the cases studied positive Aschheim-Zondek tests were obtained, yielding assays of from 3,000 to $1,000,000$ mouse units. The qualitative Friedman test was found to be positive in nine cases.

Hamburger ${ }^{12}$ reported that the oestrogen output in patients with chorionepithelioma of the testis is usually very high. He also succeeded in demonstrating human chorionic gonadotrophin activity in extracts of tumour tissue and concluded that the growth itself, and not the anterior pituitary, was responsible for the hormone production. There is no doubt that ' chorionic' testicular tumours, and metastases arising therefrom, which are capable of elaborating chorionic gonadotrophin, also possess the ability to elaborate oestrogens, and it is in all probability the oestrogens which are responsible for the symptom of gynaecomastia.

\section{Discussion}

The more one reflects upon the mechanisms of hormonal changes resulting from tumours of the testis the more it is realized how little is known about the normal physiology of testicular function. There is no doubt that the testis, besides elaborating androgens, also produces oestrogens.

Goldzieher and Roberts ${ }^{11}$ detected the presence of oestradiol-1 $\beta$ in human testicular tissue. Diczfalusy $^{8}$ has shown that pooled human semen contains oestradiol- $17 \beta$, oestrone and oestriol. Various authors, Vidgoff et al. $^{\mathbf{3 7}}$ and Berthrong ${ }^{2}$ have suggested that the Sertoli cells are responsible for producing oestrogens and there is much evidence to support this view. Normal oestrogen excretion in man is as follows: Oestriol $3.5 \mathrm{\mu g}$. per 24 hours, oestrone $5.4 \mu \mathrm{g}$. per 24 hours, oestradiol-1 $7 \beta$ I.5 $\mu \mathrm{g}$. per 24 hours. ${ }^{5}$ The testis is unique in that it is the only endocrine organ in the body producing two quite different hormones side by side, each with separate and often opposing effects on the body.

It is by the harmonious balance of these hormones that testicular tissue exerts its influence and so affects the character, outlook and behaviour of the individual. Just how the fine balance is maintained is not known with any degree of certainty, although the pituitary has some very important controlling influence. The interstitial cell-stimulating hormone (ICSH) of the anterior pituitary is thought to stimulate the interstitial cells of the testis to produce testosterone. The follicular-stimulating hormone (FSH) is supposed to stimulate the development of the germinal epithelium at puberty and enables normal spermatogenesis to continue during adult life. Oestrogen will suppress the secretion of FSH. Similarly, testosterone checks further secretion of ICSH. Thus reciprocity exists between the testis and the pituitary through the so-called ' feed-back' mechanism. However, Heller and Nelson, ${ }^{14}$ and McCullagh and $\mathrm{Hruby}^{23}$ demonstrated that androgens are relatively weak inhibitors of pituitary gonadotrophic secretion, compared with oestrogens, and Klinefelter et $a .^{20}$ have suggested that the action of testosterone in inhibiting pituitary gonadotrophin may depend on its conversion to oestrogens. It is well known that testosterone can be easily converted into oestrogens by the tissues. ${ }^{1,13,39}$ Nevertheless, whatever balance is maintained by the pituitary between the two types 
of sex hormones, it undoubtedly breaks down in the case of an interstitial cell tumour of the testis occurring before puberty. The tumour produces an excess of androgens which do not seem to be ' damped down' or controlled by any ' feed-back' mechanism and are responsible for the seemingly uncontrolled effects of precocious puberty. The identical tumour occurring in an adult after puberty has a completely different effect. It would seem here that the controlling influence of the pituitary is over-successful and excessive amounts of oestrogen are produced to counteract the secretions of the interstitial tumour cells. The result of this excess of oestrogen production is feminization.

Before puberty the testosterone elaborated by the testis may be chemically different and may not have the same effect as an inhibitor of pituitary gonadotrophin, although hormonally capable of producing the changes of puberty. After puberty the type of testosterone may be a more active inhibitor of pituitary gonadotrophin and may be more easily converted into oestrogen. This would explain, in part anyway, the totally different effects of an interstitial cell tumour in an adult and a child.

It is likely that the testis functions quite differently before and at the time of puberty compared with its function in later adult life.

Hooker, ${ }^{17}$ in studying young bulls at the time of puberty, when the accessory sex organs develop suddenly, found that there was no correspondingly large or sudden increase in the content of androgen in the testes. Presumably, he says, it is not the actual level of androgen in the testes, but rather the responsiveness of the accessory organs to the androgen, which undergoes a sudden rise at puberty. This difference in responsiveness of the accessory organs may be, in fact, due to a slight difference or modification in the type of androgen produced at puberty.

Another possibility is that an interstitial cell tumour elaborates androgens (as one would expect) at the beginning of its growth, and in an adult symptoms of 'increased virilism', so obvious in young children, may pass unnoticed. As the tumour enlarges, however, and becomes more autonomous it may lose its secreting ability. Its original androgen production, however, may have engendered an 'oestrogenic' response from the pituitary, which may continue and be responsible for the feminizing symptoms. Yet another explanation for the paradoxical behaviour of these tumours in adults is that excessive androgenic hormones produced by the tumour are converted to oestrogens, and there is ample evidence that this conversion can and does take place.

The cause of the feminizing symptoms which occur in Sertoli cell tumours, in 'gonadal stromal tumours' and in chorionepithiolomata of the testis is presumably the excessive oestrogen elaboration by the tumour cells and would not seem so difficult to account for as in the case of the interstitial cell tumours.

\section{Conclusion}

The symptoms of feminization which accompany certain testicular tumours are sometimes difficult to explain, and this is undoubtedly true with regard to interstitial cell tumours, which are responsible for such different symptoms in the two age groups. It is hardly surprising, however, when one considers how little is known about the details of normal testicular function and the mechanisms which are responsible for the changes occurring at puberty.

The tumours which have been described should be more fully investigated, as so far information about them is scanty and only comparatively few reports of hormonal assays are available. Preoperative and post-operative hormonal assays and, where possible, biosynthetic studies incorporating tumour tissue, should be performed in each case. Only then can we hope to advance our knowledge of both normal and abnormal testicular function. An ideal report on the results of investigations should include hormone assay of oestrogens and I 7-ketosteroids and quantitative Aschheim-Zondek tests, both before and after orchidectomy, anc histological report on the section of the tumour and biosynthetic studies incorporating tumour tissue. It is realized that few hospitals are equipped for such examinations, but feminizing tumours of the testis are rare enough to warrant full investigation at suitable centres.

\section{Summary}

Some rare testicular tumours, capable of causing symptoms of feminization, are described. The literature is reviewed and some speculations are made regarding the mechanisms whereby the changes in endocrine balance are brought about. A plea is made for more complete investigation of these tumours from a functional and biochemical point of view.

\section{Acknowledgments}

I wish to convey my thanks to Mr. A. W. Badenoch, M.D., Ch.M., F.R.C.S., of St. Bartholomew's Hospital, and R. M. Mulligan, M.D., Professor of Pathology in the University of Colorado Medical Centre, for help and advice, and also to Dr. R. R. Rember, M.D., of the Department of Pathology, and Mr. Jack. Fason, of the Photographic Department, Denver Veterans' Administration Hospital, for their kind co-operation and advice in preparing the illustrations.

Continued on page 200. 
the normal adrenal occurs in Conn's syndrome, it is confined to the fasciculata.

Removal of the adenoma may be followed by a period of mild aldosterone insufficiency in which the electrolyte abnormalities are reversed, hypotension may occur, and glomerular filtration rate decrease. Sometimes the blood pressure falls to normal after operation but rises again a few months later. In such cases the remission is probably due to hypoaldosteronism.

The differentiation of Conn's syndrome from other causes of hypertension with hypokalaemia may be extremely difficult. Cases of renal tubular acidosis or Fanconi syndrome can now be clearly distinguished by the presence of metabolic acidosis and the absence of increased mineralocorticoid activity. Fitzgerald et al., ${ }^{8}$ however, reported a case of malignant hypertension with potassium depletion, alkalosis and increased urinary aldosterone in whom removal of one hyperplastic adrenal arrested the losses of potassium, but removal of both failed to alter the course of the hypertension. Several other cases of hypokalaemia with hypertension have since been recorded in whom no primary adrenal abnormality (i.e. an adenoma) was present. In one instance reduction of blood pressure by means of hypotensive drugs corrected the hypokalaemia. ${ }^{12}$ Recently Dollery, Shackman and Shillingford ${ }^{7}$ have described two patients with malignant hypertension and hypokalaemia who were found to have unilateral obstruction of the renal artery. In both cases the hypokalaemia and in one the hypertension were cured by nephrectomy. The investiga- tion of such patients should therefore include renal arteriography as well as intravenous pyelography. Urinary pressor amines must also be measured. In doubtful cases surgical exploration $c$ of the adrenals is indicated and should be carried out without delay.

\section{REFERENCES}

I. BARRET'T, P. K. M., REES, J. R., and MARRACK, D. (1959), Brit. med. F., ii, 1047.

2. BROWN, M. R., CURRENS, J. H., and MARCHAND, J. F. (1944), F. Amer. med. Ass., 124, 545.

3. CHALMERS, T. M., FITZGERALD, M. G., JAMES, A. H., ஜै and SCARBOROUGH, H. (1956), Lancet, i, 127.

4. CONN, J. W., and LOUIS, L. H. (1950), F. clin. Endocr., 10, 12.

5. CONN, J. W. (1955), f. Lab. clin. Med., 45, 6.

6. CONN, J. W., and LOUIS, L. H. (1956), Ann. intern. Med., 44, $I$.

7. DOLLERY, C. T., SHACKMAN, R., and SHILliNGFORD, J. (1959), Brit. med. F., ii, 1367.

8. FITZGERALD, M. G., FOURMAN, P., JAMES, A. H., and SCARBOROÚGH, H. (1957), Scot. med. F., 2, 473.

9. FOYE, L. V., Jnr., and FEICHTMEIR, T. V. (I955), Amer. ? F. Med., 19, 966 .

10. GRUNDY, H. M., and SIMPSON, S. A. (1952), Nature, $\vec{\omega}$ 169, 795 .

I I. HEWLETT, J. S., MCCULLAGH, E. P., FARRELL, G. L., $\overrightarrow{0}$ DUSTAN, H. P., and POUTASSE, E. F. (1957), f. Amer. med. Ass., 164, 719.

12. HILDREN, T., and KROGSGAARD, A. R. (1958), Amer. F. med. Sci., 236, 487 .

13. LOEB, R. F. ATCHLEY, D. W., BENEDICT, E. M., and LELAND, J. (1933), f. exp. Med., 57, 775.

I4. MADER, I. J., and ISERI, L. T. (1955), Amer. f. Med., $\subseteq$ I9, 976 .

15. MILNE, M. D., MUEHRCKE, R. C., and AIRD, I. (I95/8 Quart. F. Med., 26, 3 I 7.

16. ROSS, E. J. (1959), 'Aldosterone'’ Oxford: Blackwell Scientif Publications Ltd.

17. ROSS, E. J. (1960), F. clin. Endocr. In press.

18. SCHWARTZ, WV. B., and RELMAN, A. S. (1953), f. clin. Invest., 32, 258.

19. SIMPSON, S. A., TAIT, I. F., WETTSTEIN, A., NEHER, R., VON EUW, J., SCHINDLER, O., and REICHSTEIX, T.'(1954), Experientia (Basel), ro, 132.
References continued from page 196-Paton Philip.

\section{REFERENCES}

I. BAGGETT, B., ENGEL, L. L., SAVARD, K., and DORFMAN, R. I. (1956), 7. biol. Chem., 221, 93 I.

2. BERTHRONG, M., GOODWIN, W. E., and SCOTT, W. W. (I049) ₹. clin. Endoct., $9,579$.

BONSER, G. M., and ROBSSON, J. M. (1940), f. Path. Bact.,

4. BREW.ं. J. I. (1946), Arch. Path. (Chicago), 4I, 580.

5. BROWN, J. B. (I955), Mem. Soc. Endocrinol,; 3, I.

6. COOK, C. D., GROSS, R. E., LANDING, B. H., and ZYGMUNTÖWICZ, A. S. (1952), $\mathcal{F}$. clin. Endocr., 12, 725

7. DECOURT, J., TOURNEUR, R., and LOUCHART, J. (1957), Ann. Éndocr. (Paris), 18 (5), 780 .

8. DICZFẢLUSY, E. (1954), Acta. endocr. (Kbh.), 15, 317.

9. FRIEDMAN, N. B., and MOORE, R. A. (1946), Milit. Surg.

10. GILBERT, J. B. (1 940), 7. Crol. (Baltimore), 44, 345.

11. GOLDZIEHER, J. W., and ROBERTS, I.'S. (1952), f. clin. Endocr. 12, 143 .

12. HAMBURGER, C. (1938), 'Les Hormones Sexuelles,' p. 345 Ed. L. Brouha. Paris: Hermann. Quoted by J. A. Loraine, 'The Clinical Application of Hormone Assay,' 1958 . London: Livingstone.

13. HEARD, R. D. H., JELLINCK, P. H., and O'DONNELL, $\mathrm{V}$. J. (1 955), Endocrinology, 57, 200.

34. HELLER, C. G., and NELSON, W. O. (1945), f. clin. Endocr.,

15. HERMANN, W. L., BUCKNER, F., and BASKIN, A. (1958), F. clin. Endocr., 18, 834 .

17. HOOKER, C. W. (1948), Rec. Progr. Hormone Res., 3, 173.

18. HUGGINS, C., and MÓLLDER, P. V. (1945), Cancer Res., 5, 5 I0.
19. INNES, J. R. M. (1942), f. Path. Bact., 54, 485.

20. KLINEFELTER, H. F., REIFENSTEIN, E. C., and ALBRIGHT, F. (1942), F. clin. Endocr., 2, $11,615$.

21. KRUCKMANN, I. (1936-37), Arch. Path. Anat., 298, 6r9, as quoted by Innes.

22. MCCULLAGH, E. P., and ROSSMILLER, H. R. (r94I), F. clin. Endocr., $\mathbf{T}, 496$.

23. McCULLAGH, E. P., and HRUBY, F. J. (I 949), Ibid., 9, I I 3. 24. MOSTOFI, F. K. THEISS, F. A., and ASHLEY, D. J. B. (1959), Cancer, 12, 5, 944 .

25. NEW.NS, C. H. (1952), Brit. F. Surg., 39, 379.

26. PEYRON, A. (1922), Bull. Ass. frans. Cancer, 11, 215.

27. PHILIP, P. P. (1959), Proc. roy. Soc. Med., 52, in.

28. PICK, L. (1905), Arch. Gynak., 76, 191 .

29. PICK, L. (1916), Berl. klin. Wschr., 53, I 173.

30. SHIMKIN, M. B., GRADY, H. G., and ANDERIONT,

3r. STALKER, A. L., and HENDRY, W. T. (1952), f. Path. Bact., 64, $16 \mathrm{r}$.

32. TEILÜM, G. (1944), Acta obstet. gynec. scand., 24, 480 .

33. TEILLM, G. (1949), F. clin. Endocr., 9, $30 \mathrm{r}$.

34. TEILLM, G. (1958), Cancer, 2, 769 .

35. TWOMBLY, G. H., MEISEL, D., and STOUT, A. P. (1949),

36. VENNING, E8. E., HOFFMAN, M. M., and BROWNE, J. S. L. (1942), F. biol. Chem., 146, 369. (1 939), Endocrinology, 25, 39 $\mathrm{r}$.

38. VINES, H. W. C. (I940), 'Green's Manual of Pathology,' I6th edition, p. 940. London.

39. WEST, C. D., DAMAST, B. L., SARRO, S. D., and PEARSON, O. H. (1956), Ұ. biol. Chem., 218, 409.

40. WITSCHI, E., and MENGERT, W. F. (I942), Ұ. clin. Endorr. 2, 279. 